\title{
MOLECULAR ANALYSIS OF AVIAN INFECTIOUS BRONCHITIS VIRUS IN QALYOUBIA GOVERNORATE DURING 2017-2018
}

\author{
HEMAT S. EL-SAYED ${ }^{1}$ and ALI M. ZANATY ${ }^{2}$ \\ ${ }^{1}$ Poultry Diseases Department, Animal Health Research Institute, Benha Branch, Benha, Egypt \\ ${ }^{2}$ Reference Laboratory for Veterinary Quality Control on Poultry Production, Animal Health Research \\ Institute, Dokki, Giza, Egypt
}

Received: 31 March 2019; Accepted: 30 April 2019

\begin{abstract}
The regular updates of molecular studies of Avian Infectious Bronchitis Virus in Egypt become imperative specially with the ongoing emergence of new strains of infectious bronchitis virus (IBV) that worsen the situation in poultry farms and causing extensive economic losses. In our study, we collect samples from twenty broiler flocks range from 18 to 36 days of age and manifested severe respiratory signs with mortality up to $30 \%$. The collected flocks located in Qalyoubia governorate during period between January 2017 to December 2018. IBV Screening in collected samples was conducted by real time rRT-PCR targeting the nucleoprotein (N) gene. A total of 12 out of 20 examined farms were positive for IBV with percentage of $(60 \%)$. Five positive IBV isolates were selected for amplification and sequencing of 400 -bp targeting the hypervariable region-3 (HVR 3) of S1 protein. Phylogenetic analysis confirmed that these viruses were closely related to each other (90-98\% identity) and were clustered to variant II (GI 23) viruses within the Egy/Var- II subgroup. The amino acids homology showed (75\% to $80 \%$ identity) between our Egyptian/Qal variants and the common vaccine used for IBV infection in Egyptian poultry farms.
\end{abstract}

Key words: Avian infectious bronchitis, Broiler, Molecular analysis, S1 gene (HVR3), Variant infectious bronchitis.

\section{INTRODUCTION}

Avian Infectious Bronchitis Virus (IBV) is a member of genus Gammacoronavirus, family Coronaviridae, order Nidovirales (De Groot et al., 2011 and King et al., 2011). Avian infectious bronchitis is one of highly contagious infectious diseases affect chicken with significant economic impact on poultry industry. Commonly, Respiratory manifestation, renal disorders, drop in egg production and both poor egg quality and quantity were seen and associated with IBV infection in chicken (Cavanagh, 2007). Some strains showing special tropism to proventriculus (Yu et al., 2001) and this feature was recorded in strain called Egypt/Qal/014p isolated from 14-day-old broilers from Egypt (EL-Nahas et al., 2017).

The IBV genome harbors of a single positivestranded RNA of approximately $27.6 \mathrm{~kb}$ in size

Corresponding author: Dr. Hemat S. EL-Sayed E-mail address: hemat.elsayed@yahoo.com Present address: Poultry Diseases Department, Animal Health Research Institute, Benha Branch, Benha, Egypt and encodes for four main structural proteins including, the phosphorylated nucleoprotien (N) protein, the membrane (M) glycoprotein, small envelope (E) protein and the spike (S) glycoprotein. The spike (S) glycoprotein, an integral membrane protein, is a major structural protein; it is cleaved post translationally into the $\mathrm{S} 1$ ( $\mathrm{N}$ terminal part) and S2 fragments (Masters, 2006). The S1 subunit contains the receptor binding site and thus plays a pivotal role in tissue tropism and inducing protective immunity (Wickramasinghe et al., 2011; Belouzard et al., 2012). In the S1 gene, three HVRs located within amino acids 38-67 (HVR-1), 91-141 (HVR-2) and 274-387 (HVR-3) that contribute in induction of both neutralizing and serotype specific antibodies (Cavanagh et al., 1988 and Moore et al., 1997). Genotyping of IBV based on S1 gene sequencing, especially the HVRs, is the most reliable way to classify IBV isolates. Usually IBV serotypes have a wide range of genetic variations in the $\mathrm{S} 1$ gene ranged from $2 \%$ to $25 \%$ (Cavanagh et al., 1992; Kingham et al., 2000). In Egypt, many strains of live attenuated and inactivated vaccines were used to control IBV. However, the outbreaks of the disease have continued to cause severe infections (Abd El Rahman et al., 2015). Different types of mutation including insertions, deletions, point mutations, 
substitutions and /or recombination of S1 gene are the main factors for emergence of new IBV variants (Alvarado et al., 2005 and Carstens, 2009).

IBV strains have been reported in chickens worldwide (Jackwood, 2012). Since the first report of isolation of IBV in Egypt in 1950 (Ahmed, (1954), ongoing scientific attention was directed in several publications for isolation and/ or detection of IBV strains from poultry farms in Egypt. Earlier IBV genotypes related to Massachusetts, D3128, D274, D08880 and 4/91 were circulating in poultry farms with nephropathy (Abdel-Moneim et al., 2006 and Jackwood et al., 2012) and with the continuing detection of IBV strains, different variants closely related to the Israeli variant strain were identified including Egyptian variant I (Egypt/Beni-Seuf/01) in 2001 (Abdel-Moneim et al., 2002) and Egyptian variant II (CK/Eg/BSU-2,3/2011) in 2012 (AbdelMoneim et al., 2012). Moreover, IS/885/00 and IS/1494/06 were dominant variants circulating in different Egyptian poultry farms causing respiratory and renal disorders (Meir et al., 2004; El-Mahdy et al., 2012; Selim et al., 2013). The continous circulation of different variants of IBV in majority of farms all over Egypt even in vaccinated ones with different strains (H120, MA5 and 4/91) was dramatically complicated the situation in poultry sector and unfortunately, allow to emerge new mutants with risk of IBV vaccination failure (Zanaty et al., 2016). Our study was a contribution in IBV surveillance in Qalyoubia which represent one of the provinces that characterized by the intensity of poultry production in Egypt for updating and monitoring the most important molecular changes in currently circulating IBV isolated form poultry farms through the partial sequence of $\mathrm{S} 1$ gene during a period between 2017-2018.

\section{MATERIALS AND METHODS}

\section{Samples collection}

In the present study, samples were collected from broiler flocks range from 18 to 36-day-old and suffering from severe respiratory signs from twenty different farms located in AL-Qalyoubia Governorate during the period from January 2017 till December 2018. The chickens were vaccinated with $\mathrm{H} 120$ vaccine against IBV at one day of age. Chickens showed respiratory signs such as gasping, coughing, sneezing and tracheal rales with white diarrhea in some cases. Necropsy showed mild to severe tracheitis with congested lung. In addition, birds were suffering from kidney lesions such as enlargement and congestion. The samples were collected as pooled homogenate from trachea and kidneys representing 20 farms were collected from diseased birds and freshly dead birds, stored in sterile Falcon tubes containing transport media with antibiotics. The samples were transported to the
Reference Laboratory for veterinary Quality control on Poultry production (RLQP), Animal Health Research Institute, Dokki, Giza, Egypt., in ice box and stored at $-80{ }^{\circ} \mathrm{C}$ until use.

\section{Virus detection and isolation}

Viral RNA was extracted directly from the samples by using QIAamp Viral RNA Mini Kit (Qiagen, Hilden, Germany), following the kit manufacturer's instructions. The virus identification was confirmed by real-time reverse transcription-polymerase chain reaction (rRT-PCR) for the presence of the neucloprotein (NP) gene of the IBV using Quantitect probe RT-PCR kit (Qiagen, Hilden, Germany), with specific primers and probe targeting the NP gene (Callison et al., 2001).

For Viral isolation, samples from trachea and kidneys were prepared as $10 \%$ tissue suspensions in transport medium (phosphate-buffered saline) $(\mathrm{pH}$ 7.4), after three cycles of freezing and thawing the suspension was clarified by centrifugation at 3000 rpm for $10 \mathrm{~min}$ and filtered through 0.45 micron membrane filters (Millipore) before inoculation in 10 day-old embryonated SPF eggs via allantoic sac route. Three passages were performed and characteristic embryo changes such as dwarfing, stunting, curling of the embryos, subcutaneous hemorrhage and ureate deposition in the mesonephros were observed between postinoculation days 2 and 7 (OIE, 2013). The harvested allantoic fluids from each sample were screened using rRT-PCR for further confirmation.

\section{Sequencing of the S1 gene}

Screening was further tested using a specific primer set for the amplifications of the HVR-3 of the S1 gene using Qiagen one-step RT-PCR (Qiagen, Hilden, Germany), according to (Adzhar et al., 1997). Amplificates of $400 \mathrm{bp}$ were excised and purified from gels using the QIAquick Gel Extraction Kit (Qiagen, Hilden, Germany). The purified RT-PCR products were sequenced using Bigdye Terminator V3.1 cycle sequencing kit (Perkin-Elmer, Foster City, CA) and Applied Biosystems 3130 genetic analyzer (ABI, United States).

\section{Phylogenetic analysis}

Sequences similarities and relationships of the HVR-3 of the S1 gene of positive samples in the present study were compared with previously published IBV vaccine and reference strains available in the public database (NCBI, United States). Amino acids phylogenetic tree was drawn for the sequenced isolates along with other vaccine and reference strains available in the GenBank database using MEGA program version 6 (Tamura et al., 2013). A comparative analysis of deduced 
amino acids and nucleotide sequences of the HVR-3 was created using the CLUSTAL W Multiple Sequence Alignment Program, version 1.83 of MegAlign module of Lasergene DNAStar software (Ziegler et al., 2002). Sequences generated in the frame of this study were submitted to the GenBank database with accession numbers showed in Table 1.

\section{RESULTS}

Clinical reports of examined farms:

The main complaints of the majority of examined farms were summarized in the following signs, high mortalities up to $30 \%$, ruffled feathers, depression, loss of appetite, mild to severe respiratory signs in form of difficult breathing, tracheal rales, gasping, sneezing and coughing. White diarrhea in some cases was also observed. The most prominent findings at necropsy were mild to severe tracheitis with congested lung, in addition to swollen and pale kidneys and in some cases the tubules and ureters filled with ureate.

\section{Virus detection and isolation}

IBV was detected in examined samples in 12 out of 20 farms with percentage of $(60 \%)$ using rRT-PCR (Fig. 1). Virus isolation was obtained from the homogenate pool of the trachea and kidneys from each flock. The allantoic fluid from the 3rd passage of each sample was further confirmed positive using rRT-PCR.

\section{Genetic and phylogenetic characterization}

The $400 \mathrm{bp}$ amplified PCR products of the HVR-3 of $\mathrm{S} 1$ gene were obtained from the 5 positive selected samples (Fig. 2), and then the partial sequencing of HVR-3 and sequence analysis was conducted. Phylogenetic tree was constructed from the amino acid sequences of HVR-3 of the S1 protein. The results indicated that Egyptian IBV viruses in our study found to be closely related to the variant II isolates and were clustered within the Egy/Var- II subgroup (IBV-Eg-12120s-2012 and IBV/IS/885-00) and other Egyptian related strains in the GenBank (Fig. 3).

Alignment report of the S1-HVR3 for both nucleotide and deduced amino acid were performed and compared with the previously published reference and vaccine IBV strains commonly used in the field (H120, Ma5, D274, 4/91,1/96 and CR88121) as well as original Egyptian viruses of Egy/Var- I and Egy/Var- II. In comparison to vaccine strains used in Egypt, Egy/ Var- II strains isolated in this study showed identity from $75 \%$ to $80 \%$ for vaccinal strains H120, Ma5, 4/91, CR88 and D274 (Table, 2). In the meantime, strains shared $90 \%$ to $98 \%$ amino acid with each other according to sequence of HVR3 (Table, 2)

Table 1: Data including time of collection, ages of birds and accession no. of Infectious bronchits virus in the present study.

\begin{tabular}{cccc}
\hline Isolate name & Date of collection & Age of birds/d & GeneBank accession number \\
\hline IBV- EGY/QAL-1-2017 & 2017 & 35 & MK492508 \\
\hline IBV- EGY/QAL-2-2017 & 2017 & 24 & MK492509 \\
\hline IBV- EGY/QAL-3-2018 & 2018 & 32 & MK492510 \\
\hline IBV- EGY/QAL-4-2018 & 2018 & 36 & MK492511 \\
\hline IBV- EGY/QAL-5-2018 & 2018 & 25 & MK492512
\end{tabular}




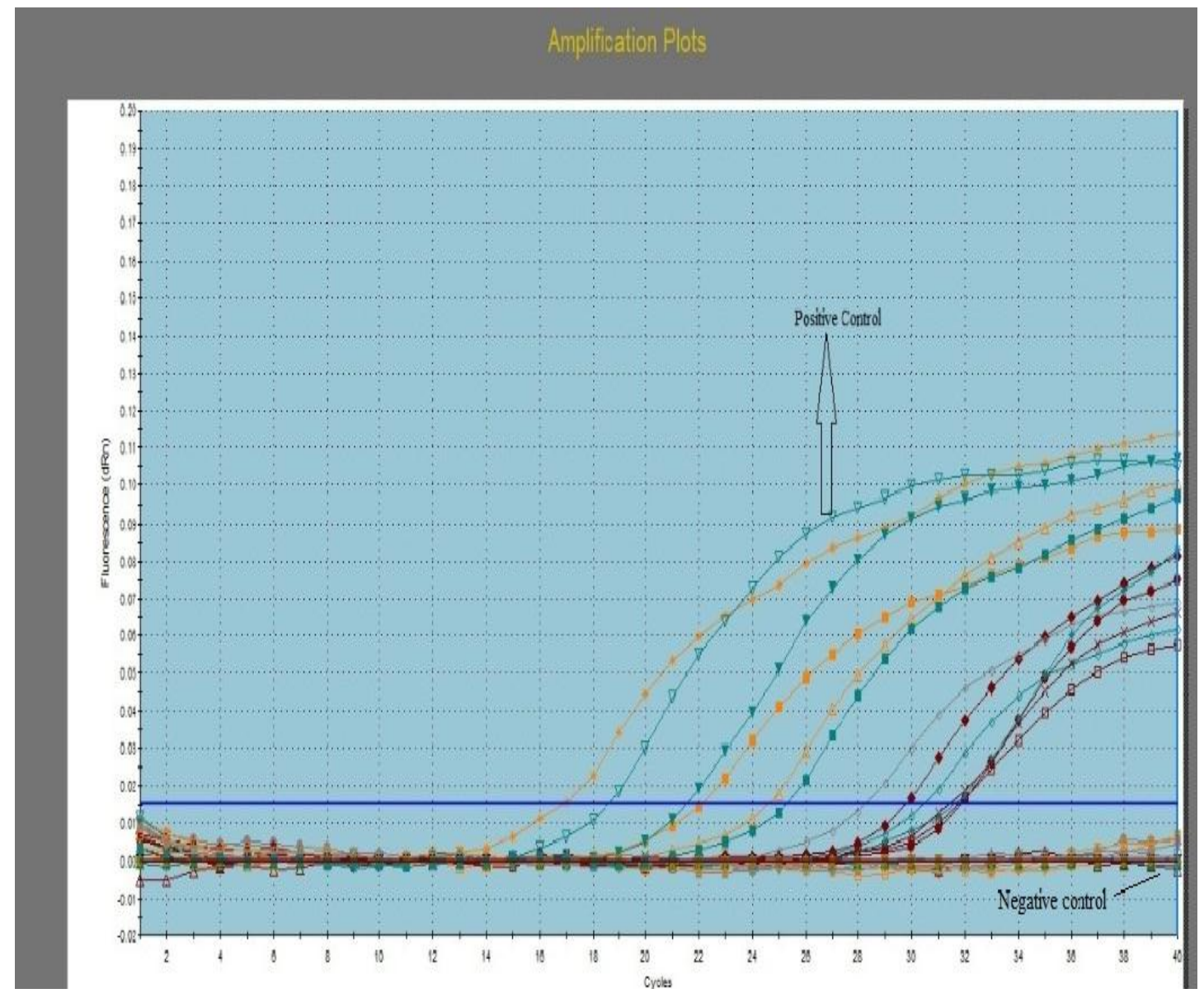

Fig. 1: Amplification curve for IBV (N) gene rRT- PCR.

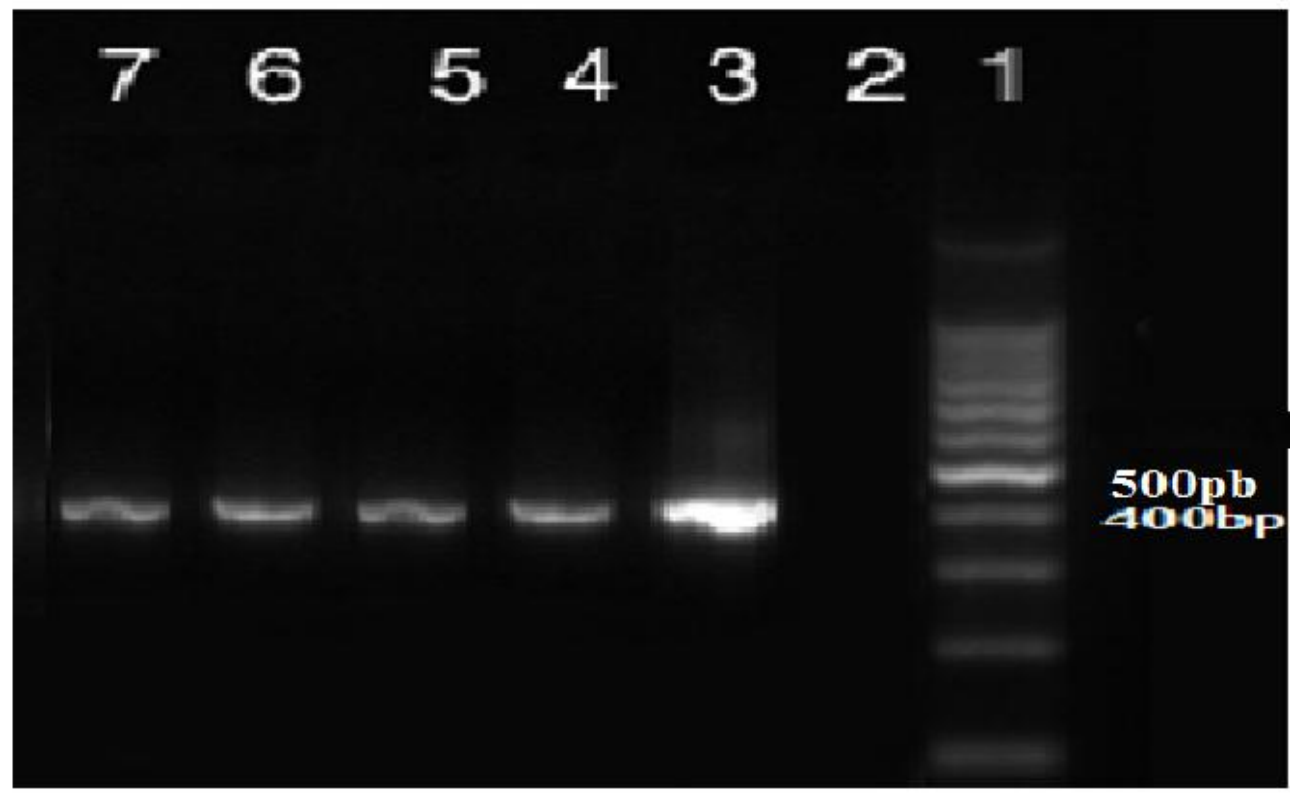

Fig. 2: Gel electrophoresis shows the result of PCR products of five selected isolates.

1 - Ladder

2 - Negative control

3 - Sample 1

4 - Sample 2

5 - Sample 3

6 - Sample 4

7 - Sample 5 


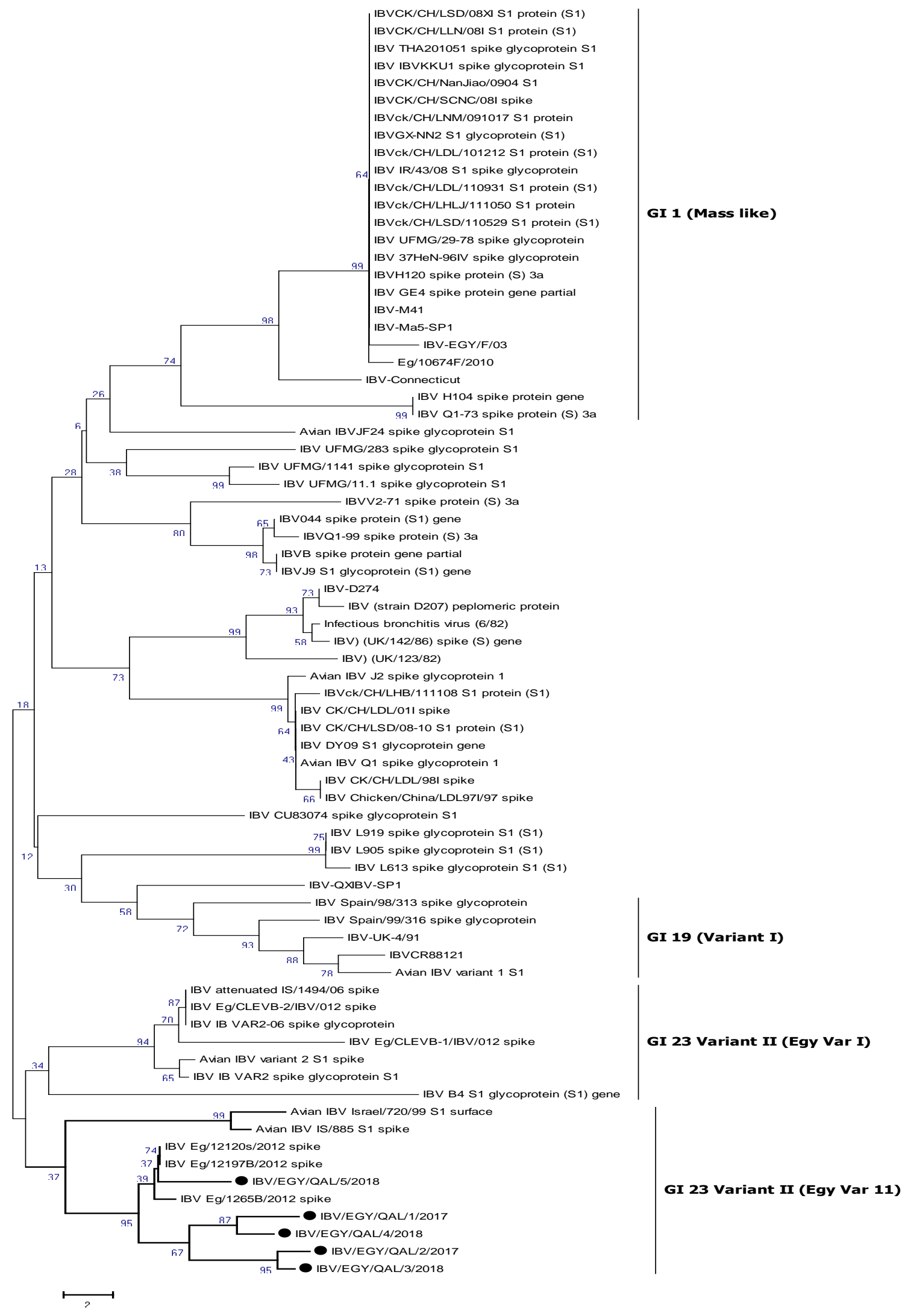

Fig. 3: Phylogenetic tree representing the partial amino acid sequences of the $\mathrm{S} 1$ gene for 5 avian infectious bronchitis virus isolates (marked with black circle) with other related infectious bronchitis virus and vaccine strains. 
IBV-IB-VAR2-06-

VVYRETSVNTTLVLTNETFTNVSNASPNTGGVNT INIYQTQTAQSGYYNFNFSFLSSFVYKQSDFMYGSYHPKCDFRPETINNGLWFNSLSVSLAYGPLQ

BV-attenuated-IS-1494-06-spike

Avian-IBV-variant-1-S1

IBV-EGY-F-03

IBV-Eg-CLEVB-1-IBV-012

Avian-IBV-IS-885-S1-spike

BV- (strain-D207) -

IBV-Ma5-SP1

IBV-Connecticut

IBV-M41

IBV-D274

IBV-QXIBV-SP1

IBV-UK-4-91

IBVCR88121

IBV-H120-

IBV-EGY/QAL-1-2017

IBV-EGY/QAL-2-2017

IBV-EGY/QAL-3-2018

IBV-EGY/QAL-4-2018

IBV-EGY/QAL-5-2018

Fig. 4: Sequence alignment for the amino acids of S1 gene for the 5 isolates of the study; vaccine strains and the reference strains.

Table 2: Nucleotide and deduced amino acid identities of infectious bronchitis virus Egyptian isolates with other selected references and vaccine strains from different serotypes.

\begin{tabular}{|c|c|c|c|c|c|c|c|c|c|c|c|c|c|c|c|c|c|c|c|c|}
\hline Sequence name & 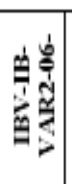 & 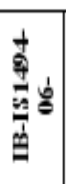 & 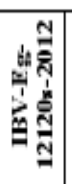 & 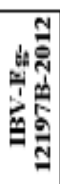 & 要 & $\begin{array}{l}y \\
0 \\
0 \\
0\end{array}$ & 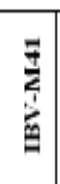 & 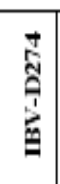 & 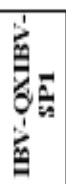 & 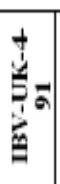 & 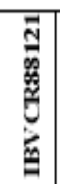 & 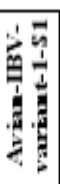 & 若 & 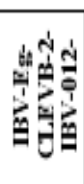 & 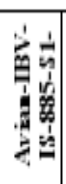 & 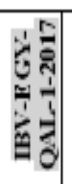 & 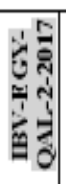 & 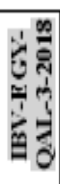 & 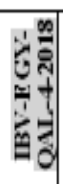 & 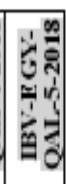 \\
\hline \multicolumn{21}{|c|}{ NUCLEOTIDE IDENTITY \% } \\
\hline IBV-IB-VAR2-06 & D & $100 \%$ & $89 \%$ & $89 \%$ & $81 \%$ & $80 \%$ & $81 \%$ & $82 \%$ & $82 \%$ & $82 \%$ & $80 \%$ & $81 \%$ & $90 \%$ & $100 \%$ & $90 \%$ & $88 \%$ & $87 \%$ & $87 \%$ & $88 \%$ & \\
\hline IBV-IS-1494-06- & $100 \%$ & D & $89 \%$ & $89 \%$ & $81 \%$ & $80 \%$ & $81 \%$ & $82 \%$ & $82 \%$ & $82 \%$ & $80 \%$ & $81 \%$ & $90 \%$ & $100 \%$ & $90 \%$ & $88 \%$ & $87 \%$ & $87 \%$ & $88 \%$ & \\
\hline IBV-Eg-12120s-2012 & $90 \%$ & $90 \%$ & $\mathbb{D}$ & $100 \%$ & $80 \%$ & $79 \%$ & $80 \%$ & $80 \%$ & $81 \%$ & $80 \%$ & $79 \%$ & $80 \%$ & $99 \%$ & $89 \%$ & $90 \%$ & $97 \%$ & $96 \%$ & $96 \%$ & $96 \%$ & \\
\hline IBV-Eg-12197B-2012 & $90 \%$ & $90 \%$ & $100 \%$ & D & $80 \%$ & $79 \%$ & $80 \%$ & $80 \%$ & $81 \%$ & $80 \%$ & $79 \%$ & $80 \%$ & $99 \%$ & $89 \%$ & $90 \%$ & $97 \%$ & $96 \%$ & $96 \%$ & $96 \%$ & \\
\hline IBV-Ma5-SPI & $79 \%$ & $79 \%$ & $81 \%$ & $81 \%$ & D & $97 \%$ & $99 \%$ & $82 \%$ & $79 \%$ & $78 \%$ & $76 \%$ & $77 \%$ & $80 \%$ & $81 \%$ & $80 \%$ & $79 \%$ & $79 \%$ & $78 \%$ & $78 \%$ & \\
\hline IBV-Connecticut & $78 \%$ & $78 \%$ & $80 \%$ & $80 \%$ & $93 \%$ & D & $98 \%$ & $81 \%$ & $79 \%$ & $78 \%$ & $77 \%$ & $78 \%$ & $79 \%$ & $80 \%$ & $82 \%$ & $78 \%$ & $78 \%$ & $78 \%$ & $78 \%$ & \\
\hline IBV-M4I & $79 \%$ & $79 \%$ & $81 \%$ & $81 \%$ & $100 \%$ & $93 \%$ & $\mathbb{D}$ & $82 \%$ & $79 \%$ & $79 \%$ & $77 \%$ & $78 \%$ & $80 \%$ & $81 \%$ & $81 \%$ & $79 \%$ & $79 \%$ & $79 \%$ & $79 \%$ & \\
\hline IBV-D274 & $83 \%$ & $83 \%$ & $82 \%$ & $82 \%$ & $78 \%$ & $76 \%$ & $78 \%$ & D & $81 \%$ & $83 \%$ & $83 \%$ & $82 \%$ & $81 \%$ & $82 \%$ & $79 \%$ & $80 \%$ & $79 \%$ & $79 \%$ & $79 \%$ & \\
\hline IBV-QXIBV-SPI & $86 \%$ & $86 \%$ & $83 \%$ & $83 \%$ & $76 \%$ & $76 \%$ & $76 \%$ & $83 \%$ & ID & $83 \%$ & $81 \%$ & $82 \%$ & $82 \%$ & $82 \%$ & $82 \%$ & $80 \%$ & $79 \%$ & $79 \%$ & $79 \%$ & \\
\hline IBV-UK-4-91 & $83 \%$ & $83 \%$ & $83 \%$ & $83 \%$ & $74 \%$ & $74 \%$ & $74 \%$ & $83 \%$ & $87 \%$ & $\mathbb{D}$ & $98 \%$ & $98 \%$ & $81 \%$ & $82 \%$ & $81 \%$ & $80 \%$ & $79 \%$ & $79 \%$ & $80 \%$ & \\
\hline IBVCR88121 & $82 \%$ & $82 \%$ & $81 \%$ & $81 \%$ & $72 \%$ & $73 \%$ & $72 \%$ & $83 \%$ & $86 \%$ & $95 \%$ & ID & $98 \%$ & $79 \%$ & $80 \%$ & $79 \%$ & $79 \%$ & $77 \%$ & $78 \%$ & $79 \%$ & \\
\hline Avian-IBV-variant-1-S1 & $80 \%$ & $80 \%$ & $81 \%$ & $81 \%$ & $72 \%$ & $73 \%$ & $72 \%$ & $80 \%$ & $85 \%$ & $95 \%$ & $96 \%$ & ID & $81 \%$ & $81 \%$ & $80 \%$ & $80 \%$ & $79 \%$ & $79 \%$ & $80 \%$ & \\
\hline IBV-Eg-1265B-2012- & $90 \%$ & $90 \%$ & $99 \%$ & $99 \%$ & $80 \%$ & $79 \%$ & $80 \%$ & $82 \%$ & $83 \%$ & $83 \%$ & $81 \%$ & $81 \%$ & ID & $90 \%$ & $90 \%$ & $97 \%$ & $96 \%$ & $96 \%$ & $97 \%$ & \\
\hline IBV-Eg-CLEVB-2-BBV-- & $100 \%$ & $100 \%$ & $90 \%$ & $90 \%$ & $79 \%$ & $78 \%$ & $79 \%$ & $83 \%$ & $86 \%$ & $83 \%$ & $82 \%$ & $80 \%$ & $90 \%$ & ID & $90 \%$ & $88 \%$ & $87 \%$ & $87 \%$ & $88 \%$ & \\
\hline Avian-IBV-IS-885-S1 & $90 \%$ & $90 \%$ & $90 \%$ & $90 \%$ & $76 \%$ & $78 \%$ & $76 \%$ & $80 \%$ & $84 \%$ & $82 \%$ & $80 \%$ & $79 \%$ & $90 \%$ & $90 \%$ & D & $88 \%$ & $87 \%$ & $87 \%$ & $88 \%$ & \\
\hline IBV-EGY-QAL-1-2017 & $84 \%$ & $84 \%$ & $92 \%$ & $92 \%$ & $75 \%$ & $74 \%$ & $75 \%$ & $79 \%$ & $78 \%$ & $78 \%$ & $76 \%$ & $76 \%$ & $93 \%$ & $84 \%$ & $85 \%$ & $\mathrm{ID}$ & $96 \%$ & $97 \%$ & $98 \%$ & \\
\hline IBV-EGY-QAL-2-2017 & $83 \%$ & $83 \%$ & $91 \%$ & $91 \%$ & $75 \%$ & $74 \%$ & $75 \%$ & $77 \%$ & $77 \%$ & $78 \%$ & $75 \%$ & $76 \%$ & $90 \%$ & $83 \%$ & $81 \%$ & $90 \%$ & D & $99 \%$ & $95 \%$ & \\
\hline IBV-EGY-QAL-3-2018 & $84 \%$ & $84 \%$ & $91 \%$ & $91 \%$ & $75 \%$ & $74 \%$ & $75 \%$ & $78 \%$ & $78 \%$ & $79 \%$ & $76 \%$ & $77 \%$ & $92 \%$ & $84 \%$ & $83 \%$ & $92 \%$ & $98 \%$ & $\mathbb{D}$ & $96 \%$ & \\
\hline IBV-EGY-QAL-4-2018 & $85 \%$ & $85 \%$ & $93 \%$ & $93 \%$ & $76 \%$ & $75 \%$ & $76 \%$ & $79 \%$ & $79 \%$ & $79 \%$ & $77 \%$ & $77 \%$ & $94 \%$ & $85 \%$ & $86 \%$ & $96 \%$ & $91 \%$ & $93 \%$ & $\mathrm{ID}$ & \\
\hline IBV-EGY-QAL-5-2018 & $87 \%$ & $87 \%$ & $97 \%$ & $97 \%$ & $78 \%$ & $77 \%$ & $78 \%$ & $80 \%$ & $80 \%$ & $80 \%$ & $78 \%$ & $78 \%$ & $96 \%$ & $87 \%$ & $87 \%$ & $90 \%$ & $91 \%$ & $90 \%$ & $94 \%$ & \\
\hline
\end{tabular}




\section{DISCUSSION}

IBV, one of the important viruses that infect poultry flocks worldwide and recently the new variants topped the scene in Egypt and putting poultry policy makers in the face of a catastrophic crisis that represented in huge economic losses and failure of vaccination. Our study was a contribution to follow up and identify the IBV genotypes circulated in the poultry flocks in Qalyoubia locality. Herein, we examined twenty broilers farms distributed in different centers followed the Qalyoubia governorate, the majority of complaints of examined farms were high mortalities up to $30 \%$, with the inspection of affected birds the most common signs were seen in form of respiratory manifestation including, difficult breathing, tracheal rales, sneezing and coughing. On necropsy, the frequently PM findings were seen in form of mild to severe tracheitis with caseous exudate in some cases, airsacculitis and swollen, congested and pale kidney with distended ureter with urates. Similar signs and PM findings were observed in previous study isolated IBV from poultry flocks in Delta region in Egypt during 2014-2015 (Sultan et al., 2017).

The confirm and on-time diagnosis was urgent need specially after increasing incidence of mixed infection in commercial Egyptian poultry farms nowadays. RRT-PCR was rapid, sensitive and specific molecular diagnostic tool for detection and screening of IBV suspect samples (Naguib et al., 2017). In our study the screening conducted on 20 different farms for the presence of the neucloprotein (N) gene sequence of the IBV using rRT-PCR confirmed IBV in 12 farms with percentage of $60 \%$.

Recently IBV variants are widely distributed in many countries all over the world with more than 20 different serotype (Sjaak de Wit et al., 2011). In Egypt, from the available molecular data reported during the few years ago, the IBVs were evolved into two groups classic (GI-1) and variant (GI-23), the last one were subdivided into two subgroups (Egy/Var- I and Egy/Var- II ) according to the sequence of the HVR-3 (Abdel-Moneim et al., 2012 and Ganapathy et al., 2015). The viruses clustered to the subgroup Egy/Var- II were shown to be widely spread in Egypt in last years (Abo-Elkhair et al., 2012 and Valastro et al., 2016).

The phylogenetic analysis conducted on the selected five IBVs showed that these viruses were related to each other (90-98\% identity) according to sequence of HVR-3 and found to be closely related to the variant isolates and were clustered within the Egy/Var- II subgroup (IBV-Eg-12120s-2012 and IBV/IS/885-00) and other Egyptian related strains deposited in the GenBank database. These findings referred to the circulation of strains belongs to
Egy/Var- II in broiler flocks in Qalyoubia during 2017-2018, also our findings were agree with AbdelMoneim et al., 2012; Sultan et al., 2015; Tatar-Kis et al., 2015; Zanaty et al., 2016 and EL Samadony et al., 2017) who reported that Egyptian variant II strains were the most dominant strains circulated in Egyptian poultry flocks recently.

One of our study aims is to compare between the isolated variants circulated in poultry flocks located in Qalyoubia governorate and the vaccine strains currently used for IBV vaccination (H120, Ma5, 4/91, CR88, and D274). Herein, the comparison showed that there was $75 \%$ to $80 \%$ identity between our isolates and the mentioned vaccine strains which indicate to the wide gap of difference between the isolated viruses and the existing vaccines types which resulted in emerging of new antigenic types that increase the risk of vaccine failure. Similar observation were recorded in previous studies (Samir et al., 2014 and bdel-ELGhany et al., 2015). The small changes detected along the S1 protein lead to genetic alteration and recombination and subsequently evolve new field strains (liu and Kong, 2004), these changes arises from immunological pressure caused by the massive use of live vaccines in presence of infection with field strain (Zanaty et al., 2016), so it is necessary to evaluate the protective capabilities of the commonly used vaccine in Egypt as well as preparation of vaccine from indigenous isolates for achieving the successful control of IBV in Egypt (EL-Nahas et al., 2017).

\section{CONCLUSION}

The present study confirmed the detection and isolation of IBVs from broilers flocks in Qalyoubia governorate during 2017-2018, the Egypt/Qal strains were closely related to Egy/Var- II that dominant circulated in last years in commercial poultry farms in Egypt. Also the phylogenetic analysis showed the dissimilarities between our isolates and the currently used vaccines for IBV in Egypt. The continuous follow up through surveillance activities and preparation of vaccines from indigenous isolates were necessary issues for successful control of IBV in Egypt.

\section{CONFLICT OF INTEREST STATEMENT}

The authors declare no conflict of interest.

\section{ACKNOWLEDGEMENT}

The authors are grateful to members of Reference Laboratory for Veterinary Quality Control on Poultry Production (RLQP), Animal Health Research Institute, Dokki, Giza, Egypt, for their help in viral isolation and sequencing process. 


\section{REFERENCES}

Abdel-ELGhany, S.A.; Hussein, H.A.; Arafa, A.; Zanaty, A. and Shalaby, M.A. (2015): Molecular Characterization of Is/1494-Like Strains of Infectious Bronchitis Virus (IBV) in Commercial Breeders and Layer Chicken in Egypt During Years 2012 to 2014. Global Veterinaria. 15 (3): 278-283.

Abdel-Moneim, A.S.; Afifi, M.A. and El-Kady, M.F. (2012): Emergence of a novel genotype of avian infectious bronchitis virus in Egypt. Arch Virol. 157: 2453-2457.

Abdel-Moneim, A.S.; El-Kady, M.F.; Ladman, B.S. and Gelb, Jr.J. (2006): S1 gene sequence analysis of a nephropathogenic strain of avian infectious bronchitis virus in Egypt. Virology Journal. 3, 78.

Abdel-Moneim, A.S.; Madbouly, H.M.; Gelb, J.R. and Ladman, B.S. (2002): Isolation and identification of Egypt/Beni-Suef/01 a novel genotype of infectious bronchitis virus. Vet. Med. J. Giza., 50 (4), 1065-1078.

Abd El Rahman, S.; Hoffmann, M.; Lueschow, D.; Eladl, A. and Hafez, HM. (2015): Isolation and characterization of new variant strains of infectious bronchitis virus in Northern Egypt. Adv Anim Vet Sci; 3: 362-371

Abo Elkhair, M.; Bazid, A.I.; Abd El-Razik, A.G.; Zidan, S.A. and Sultan, H.A. (2012): Detection of avian influenza virus (subtypes $\mathrm{H} 9$ and H5) and avian infectious bronchitis virus in an outbreak associated with high mortality in poultry flocks in Egypt, -7th scientific April 2012 Fac. Vet. Med. Minufiya Univ.

Adzhar, A.; Gough, R.E.; Haydon, D.; Shaw, K.; Britton, P. and Cavanagh, D. (1997): Molecular analysis of the 793/B serotype of infectious bronchitis virus in Great Britain. Avian Pathol., 26: 625.

Ahmed, H.N. (1954): Incidence and treatment of some and N.K. Gopal, 2005. Incidence and treatment of some infectious viral respiratory diseases of poultry in Egypt. Egypt. Ph. D. Thesis. Fac. Vet. Med. Cairo University; Giza; Egypt.

Alvarado, I.R.; Villegas, P.; Mossos, N. and Jackwood, M.W. (2005): Molecular characterization of avian infectious bronchitis virus strains isolated in Colombia during 2003. Avian Dis. , 49: 494-499.

Belouzard, S.; Millet, J.K.; Licitra, B.N. and Whittaker, G.R. (2012): Mechanisms of coronavirus cell entry mediated by the viral spike protein. Viruses. 4, 1011-1033.

Callison, S.A.; Jackwood, M.W. and Hilt, D.A. (2001): Molecular characterization of infectious bronchitis virus isolates foreign to the United States and comparison with
United States isolates. Avian Dis., 45: 492499

Carstens, E. (2009): Report from the 40th meeting of the Executive Committee of the International Committee of Taxonomy of Viruses, 1571-1574

Cavanagh, D. (2007): Coronavirus avian infectious bronchitis virus. Veterinary Research. 38, 281-297.

Cavanagh, D.; Davis, P.J. and Mockett, A.P.A. (1988): Amino acids within hypervariable region 1 of avian coronavirus IBV (Massachusetts serotype) spike glycoprotein are associated with neutralization epitopes. Virus Research., 11, 141-150.

Cavanagh, D.; Davis, PJ.; Cook, JK.; Li, D.; Kant, A. and Koch, G. (1992): Location of the amino acid differences in the $\mathrm{S} 1$ spike glycoprotein subunit of closely related serotypes of infectious bronchitis virus. Avian Pathol; 21: 33-43 [PMID: 18670913 DOI: 10.1080/0307945 9208418816]

De Groot, R.J.; Baker, S.C.; Baric, R.; Enjuanes, L.; Gorbalenya, A.; Holmes, K.V.; Perlman, S.; Poon, L.; Rottier, P.J. and Talbot, P.J. (2011): Coronaviridae. In: King, A.M.Q., Adams, M.J., Carstens, E.B., Lefkowitz, E.J. (Eds.),Virus Taxonomy, Classification and Nomenclature of Viruses, Ninth Report of the International Committee on Taxonomy of Viruses, International Union of Microbiological Societies, Virology Division, Elsevier Academic Press, pp. 806-828.

El-Mahdy, S.S.; Ekram, S. and Ahmed, A. (2012): Efficacy of some living classical and variant infectious bronchitis vaccines against local variant isolated from Egypt. Nature and Science. 10, 292-299.

El-Nahas, E.M.; El-Sayed, H.S.; El-Basuni, S.S. and El-Bagoury, G.F. (2017): A genotyping of a new avian infectious bronchitis virus isolated from chickens proventriculus in Egypt. J. of Virol. Sci., Vol. 1: 54-66.

Elsamadony, H.A.; Talaat, S.M.; Sediek, M.; Gab Allah, A.; Gad, T. and Sultan, H.A. (2017): The Co-infection of Variant-II Infectious Bronchitis Virus with other Viral Infection in Broilers. Animal Health Research Journal. Vol. 5, No. 4 (B), November 2017 pp. 126133.

Ganapathy, K.; Ball, C. and Forrester, A. (2015): Genotypes of infectious bronchitis viruses circulating in the Middle East between 2009 and 2014. Virus Res. 210: 198-204.

Jackwood, M.W. (2012): Review of infectious bronchitis virus around the world. Avian Disease 56, 634-641.

King, A.M.; Lefkowitz, E.; Adams, M.J. and Carsten, E.B. (2011): Ninth Report of theInternational Committee on Taxonomy of Viruses. 
Kingham, B.F.; Keeler, C.L.; Nix, W.A.; Ladman, B.S. and Gelb, J. (2000): Identification of avian infectious bronchitis virus by Direct Automated Cycle Sequencing of the S1 gene. Avian Diseases. 44: 325-335.

Liu, S. and Kong, X. (2004): A new genotype of nephropathogenic infectious bronchitis virus circulating in vaccinated and non-vaccinated flocks in China. Avian Pathol., 33: 321-327.

Masters, P.S. (2006): The molecular biology of coronaviruses. Advanced Virus Research. 66, 193- 292.

Meir, R.; Rosenblut, E.; Perl, S.; Kass, N.; Ayali, G.; Hemsani, E. and Perk, S. (2004): Identification of a novel nephropathogenic infectious bronchitis virus in Israel. Avian Disease. 48, 635-641.

Moore, K.M.; Jackwood, M.W. and Hilt, D.A. (1997): Identification of amino acids involved in a serotype and neutralization specific epitope within the S1 subunit of avian infectious bronchitis virus. Archives of Virology. 142, 2249-2256.

Naguib, M.M.; El-Kady, M.F.; Lüschowd, D.; Hassan K.E.; Arafa, A.; El-Zanaty, A.; Hassan, M.K.; Hafez, H.M.; Grunda, C. and Hardera T.C. (2017): New real time and conventional RT-PCRs for updated molecular diagnosis of infectious bronchitis virus infection (IBV) in chickens in Egypt associated with frequent co-infections with avian influenza and Newcastle Disease viruses. Journal of Virological Methods. 245, 19-27.

OIE Terrestrial Manual (2013): Avian Infectious Bronchitis, [Chapter 2.3.2].

Samir, M.; Selim A.; Arafa, A.; Khaleil, S.; Hagag, N.; Samir, A. and Hasan, M. (2014). Molecular Diversity Between Field Isolates and Vaccinal Strains of Avian Infectious Bronchitis Virus in Egypt. Global Veterinaria. 13 (5): 820-827.

Selim, K.; Arafa, A.S.; Hussein, H.A. and ElSanousi, A.A. (2013): Molecular characterization of infectious bronchitis viruses isolated from broiler and layer chicken farms in Egypt during 2012. International Journal of Veterinary Science and Medicine 1,102-108.

Sjaak de Wit, J.J.; Cook J.K. and van der Heijden, H.M. (2011): Infectious bronchitis virus variants: a review of the history, current situation and control measures. Avian Pathol. 40: $223-235$
Sultan, H.; Abdel-Razik, A.G.; Shehata, A.A.M.; Talaat, S.; Abo-Elkhair, M.; Bazid, A.E.; Moharam, I.M. and Vahlenkamp, T. (2015): Characterization of Infectious Bronchitis Viruses Circulating in Egyptian chickens during 2012 and 2013. J Vet Sci Med Diagn. 4: 5 [DOI: 10.4172/2325-9590.1000180].

Sultan, H.A; Elsamadony, H.A.; Talaat, S.M. and Abdel-Mohsen, G.T. (2017): Molecular Epidemiology of Infectious Bronchitis Virus during 2014/2015 in Broilers in Delta region in Egypt. Animal Health Research Journal Vol. 5, No. 5, December 2017 pp. 70-79.

Tamura, K.; Stecher, G.; Peterson, D.; Filipski, A. and Kumar, S. MEGA6 (2013): Molecular Evolutionary Genetics Analysis version 6.0. Mol Biol Evol. 30: 2725-2729

Tatar-Kis, T.; Kovacs, E.W.; Felfodi Zalan, B.; Gardin, G.Y. and Palya, V. (2015): Protection against IBV variant-2 challenge achieved by day-old vaccination with combination of heterologous vaccines using various parameters for evaluation. Abstract, Proceeding, 19th World Veterinary Poultry Association Congress, CAPETOWN.

Valastro, V.; Holmes, E.C.; Britton, P.; Fusaro, A.; Jackwood, M.W.; Cattoli, G. and Monne, I. (2016): S1 gene-based phylogeny of infectious bronchitis virus: An attempt to harmonize virus classification. Infect Genet Evol. 39: 349-364.

Wickramasinghe, I.N.; de Vries, R.P.; Grone, A.; de Haan, C.A. and Verheije, M.H. (2011): Binding of avian coronavirus spike proteins to host factors reflects virustropism and pathogenicity. J. Virol. 85, 8903-8912.

Yu, L.; Jiang, Y.; Low, S.; Nam, S.J.; Liu, W. and Kwangac, J. (2001): Characterization of three infectious bronchitis virus isolates from China associated with proventriculus in vaccinated chickens. Avian Disease. 45, 416424.

Zanaty, A.; Arafa, A.S.; Hagag, N. and El-Kady, M. (2016): Genotyping and pathotyping of diversified strains of infectious bronchitis viruses circulating in Egypt. World Journal of Virology. 5 (3), 125.

Ziegler, A.F.; Ladman, B.S.; Dunn, P.A.; Schneider, A.; Davison, S.; Miller, P.G.; Lu, H.; Weinstock, D.; Salem, M.; Eckroade, R.J. and Gelb, J. (2002): Nephropathogenic infectious bronchitis in Pennsylvania chickens 19972000. Avian Dis. 46: 847-858. 


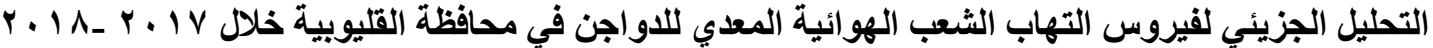 همت شفيق السبيا ، على محمود الزناتسي}

E-mail: hemat.elsayed@yahoo.com Assiut University web-site: www.aun.edu.eg

التحديث الدوري للار اسات الجزيئية لفيروس التهاب الثعب الهو ائية المعدي للاواجن في مصر أصبح ضروري وخاصة مع الظهور

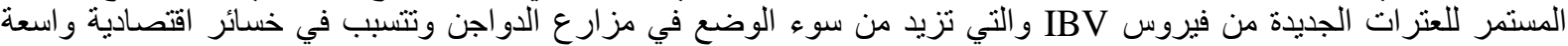

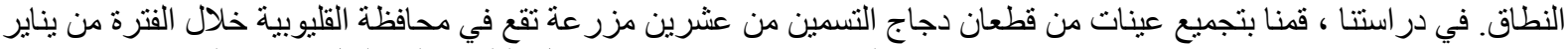

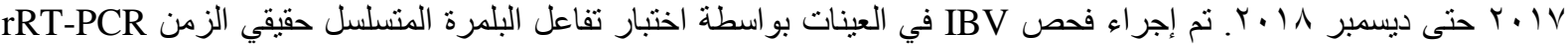

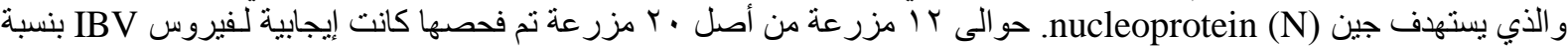

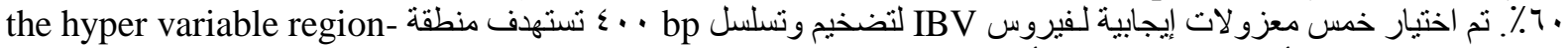

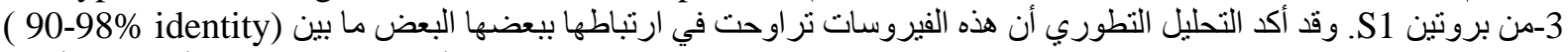

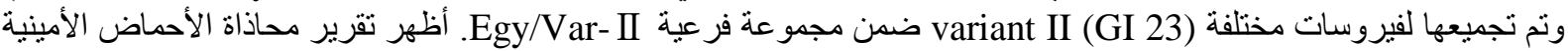

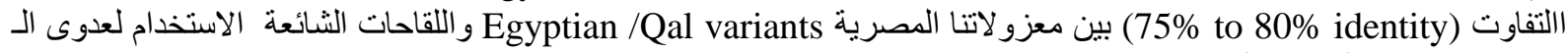
في مزارع الدو اجن المصرية. 